\title{
The potential wind erosion map of an area covered by sandy and loamy soils - based on wind tunnel measurements
}

\author{
Gábor Négyesi, József Lóki, Botond Buró, József Szabó, \\ Zsófia BaKacsi, and László PÁsztor
}

with 12 figures and 4 tables

\begin{abstract}
Summary. Wind erosion causes an enormous problem in agriculture, and the stirred-up dust influences the air quality and is harmful for human health. In the cultivated agricultural areas of Hungary, soils with different textures often suffer from wind erosion, and due to the global climate change an ever increasing risk rate can be expected. In this study we examined in a wind tunnel the thresholds of wind velocity and erodibility of 80 different soil samples originated from an area covering of approximately $5,000 \mathrm{~km}^{2}$. Afterwards, based on the resulting data the soils with different texture types were categorized in erosion risk classes. Using the experimental results and the CORINE land cover database, we compiled a potential wind erosion map for the studied area.
\end{abstract}

Key words: wind erosion, threshold wind speed, erodibility of soils

\section{Introduction}

Due to certain climatic and geographic properties, vast areas of water shortage were formed on the surface of Earth. Aridity and precipitation deficit are primarily typical in desert and semi-desert regions in tropical and temperate zones, but beyond those, it is a common phenomenon in the greater agricultural - cultivated and/or cultivable - areas as well. Because of the environmental effects of human activities, dry areas do or may form even where otherwise the actual climate conditions would not give reasons for such changes. The geomorphic action of the wind is especially strong where no vegetation cover is present, and where the kinetic wind energy is sufficient to set surface soil and rock grains in motion (SweETing \& LANCASTER 1982, AsH \& WASSON 1983).

Wind erosion presents a serious problem worldwide. According to LAL (1994) the total agricultural area afflicted by wind erosion adds up to about 550 million hectares worldwide. OLDEMAN. et al. (1991) estimated the total European agricultural areas eroded by wind as 42 million hectares. Due to the global climatic changes that give rise to extreme climate conditions, an increase in the size of endangered areas can be expected.

Geographic information systems have been used in erosion prediction. GIS is specialised computer software used to display and analyse spatial data, and are being increasingly used in soil erosion research (MCDONNELL 1998). The general approach 
for using GIS is to display factors important in an analysis as separate layers or maps in the GIS. The various layers are overlaid to determine the combination of factors to be used in the model. The application of GIS to wind erosion prediction already has been widely tested (ANDREws et al. 2002, ZовеCK et al. 2002, Fu et al. 2005). Studies reporting the location of areas susceptible to wind erosion have foundations in land degradation surveys, analysis of dust storm frequencies and aerosol indices derived from satellite imagery. These methods have been applied extensively in Africa, North America, Europe, the Middle East and China (Mezősi \& Szatmári 1998, Prospero et al. 2002, SHi et al. 2004, VIser et al. 2005). Most of the publishers combine GIS methods with different wind erosion model for wind erosion prediction and soil losses. These physical process-based models (TEAM, WEPS, RWEQ) were developed for input, processes, output and assumptions mainly in North America. A weakness of these models is that they are only applicable to relatively small areas that are known to be susceptible to wind erosion (WeBB et al. 2006). An another important limitation of these methods is that they have not provided a means for assessing dynamic changes in land susceptibility to wind erosion at scales between the field and coarser regional scales (Wевв et al. 2009). However, there is an another way to evaluate the wind erodibility of different areas: if we present static erosion hazard maps based on soil texture or wind tunnel measurements.

Wind erosion causes serious damages and losses in Hungary as well. Early studies focused primarily on sandy areas with weak fertility. According to BORsY (1974) the blowing sand areas which are most threatened by wind erosion cover no less than $20 \%$ of the total surface of the country (LóKI 2003, SzABó 2004).

Our aims - beyond the basic pedological studies and sample characterizations included determining the values of several wind erosion parameters that are important in terms of protection against erosion (such as threshold wind velocity, erodibility, etc.), as well as the construction of a potential wind erosion map for a pilot area on the basis of measured data in wind tunnel.

\section{Soils of the studied area}

We evaluated the spatial distribution of soils in the Nyírség based on three Hungarian soil databases, namely: AGROTOPO, SIMS and DKSIS (for details see PÁszTOR et al. 2012).

The Nyírség alluvial fan is situated in the north-eastern part of the Great Hungarian Plain, bounded by the Tisza River from the north and east, and mostly covered by blown sand, loess sand, and dominantly loess material on its western part. This region (fig. 1) is the largest contiguous sandy area in Hungary, whose surface was formed by both water and wind.

Typically, in the central and northern part of the Nyírség region the sand ridges have a nearly exact north-south orientation, while in the south part they tend to turn into south-west. The topsoil diversity reflects the surface morphology. Unconsolidated blown sand is characteristic on the top of the sand ridges (Protic Arenosols), and humic sandy soils (Haplic Cambisols) and banded brown forest soils (Lamellic Luvisols) on the gentle slopes, while in the dune depressions, in small, flat valleys usually hydromorphic soils (meadow and meadow-alluvial soil/Gleyic Phaeozems) cover the surface. 
In the West-Nyírség sandy loess acts as parent material of soils, where pseudomyceliar chernozems (Calcic Chernozems) and banded brown forest soils have been formed.

In the northern and central parts of the region one of the most common soil types is the banded brown forest soil. The topsoil (A-horizon) is $30-40 \mathrm{~cm}$ thick, yellowish-brown, its organic matter content is below $1 \%$, while its sand content is generally equal to or greater than $80 \%$. The grain size of about $80 \%$ of all sand particles vary between 0.05 and $0.2 \mathrm{~mm}$, while $20 \%$ of them have a greater diameter than $0.2 \mathrm{~mm}$. Organic matter- and colloid-rich bands appear in the sub-soil (B-horizon), improving the soil water management of the profile. The average thickness of the lamellas is about $1 \mathrm{~cm}$, but it can reach up to even $10 \mathrm{~cm}$. The entire profile is carbonate-free and acidic.

On the gentle slopes of the sand ridges, carbonate-free, acidic sandy soils are found (Haplic Arenosols). The sand content in the entire profile is equal to or greater than $80 \%$. The topsoil is unstructured, its organic matter content rarely exceeds $1 \%$, and the thickness of the humus layer is dominantly $30-40 \mathrm{~cm}$.

In the southern part of the region acid blown sand (Protic Arenosols) forms the higher lying surface; in such a topsoil the sand content exceeds $90 \%$. Its organic matter content is below $0.5 \%$, it is unstructured and very poor in soil colloids. Partly, below $1 \mathrm{~m}$ depth some carbonate accumulation can also appear in the profiles.

In the interdune areas between the sand ridges traces the shaping effect of fluvial action are noticeable. The topsoil of the formed meadow soils (Phaeozems) can be characterized by higher contents of organic matters and colloids, and a finer texture (clay loam and silty clay loam). The thickness of the humus layer is usually between 40$70 \mathrm{~cm}$. In some parts - because of the fluvial, calcareous, silty sediments, and due to the carbonate-rich ground-water - the profiles have neutral or slightly alkaline chemistry, and carbonate accumulation can occur below the A-horizon. As part of the hydromorphic soil complexes, small patches of salt-affected soils can also be found there.

In the western part of Nyírség the parent material of the soil is dominantly sandy loess with eolian origin, which can be characterized by good drainage, with loam and/or sandy loam mechanical composition. Mostly Chernozem soils were formed there with secondary carbonate accumulation (Calcic Chernozems), associated with Lamellic Luvisols from the east. In lower geomorphological positions gleyic soil properties also appear in the profiles (Gleyic Chernozems).

\section{Materials and methods}

\subsection{Soil sampling}

Under the present climate conditions in Hungary, wind erosion mainly occurs in the vernal months, at the beginning of the vegetational period, and almost exclusively as an effect of human activity (ploughing, tilling, cultivator disking etc.). Therefore, in the field we collected samples from the upper, ploughed layer $(0-20 \mathrm{~cm})$ of different soil types, both for the sedimentological analyses and the wind tunnel experiments. When selecting the sampling locations the soil textures were taken into consideration. For the wind erosion studies we collected a total 80 samples with targeted sampling, from different parts of the Nyírség (fig. 2). Another important aspect of the sampling 


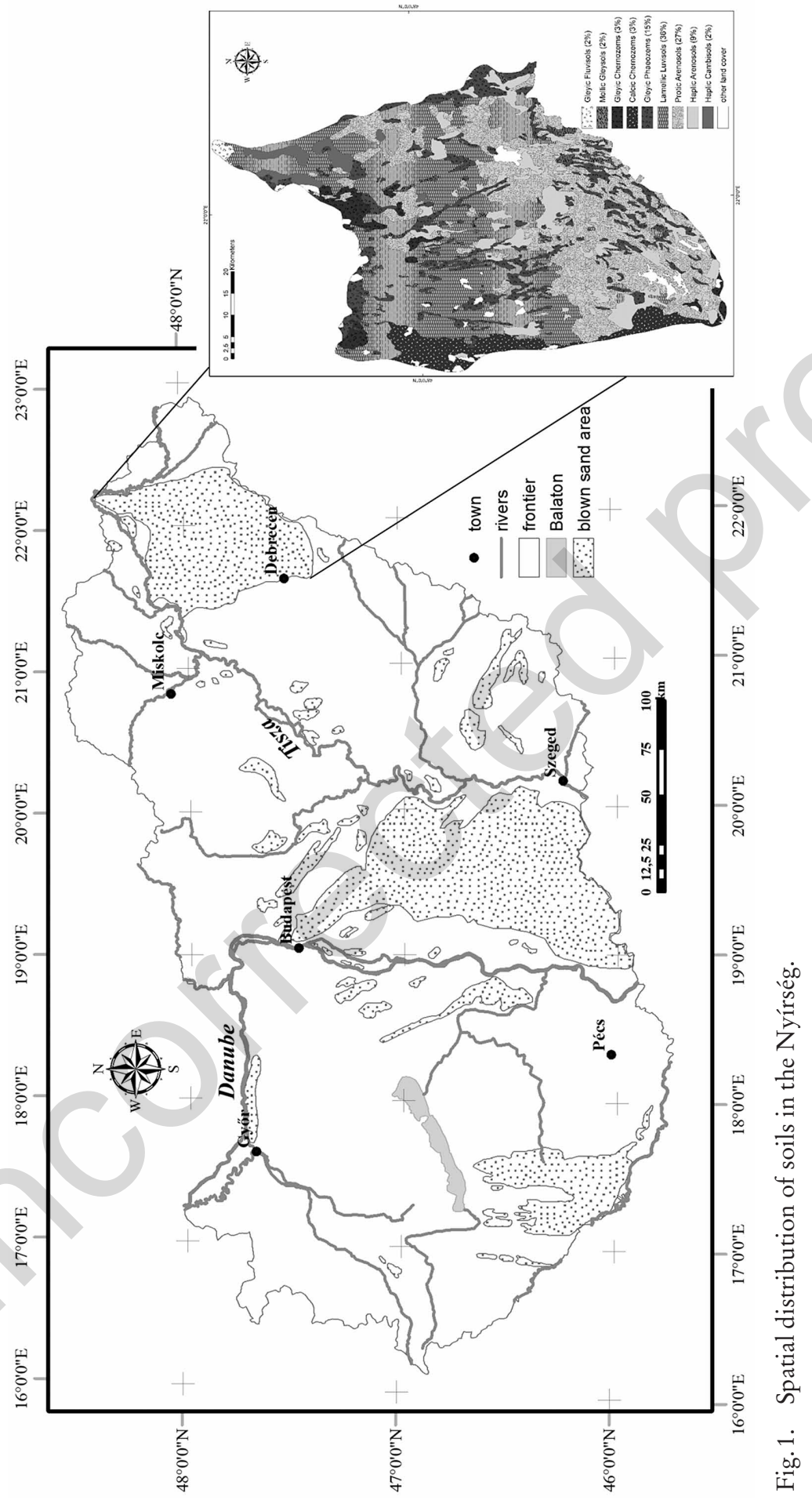




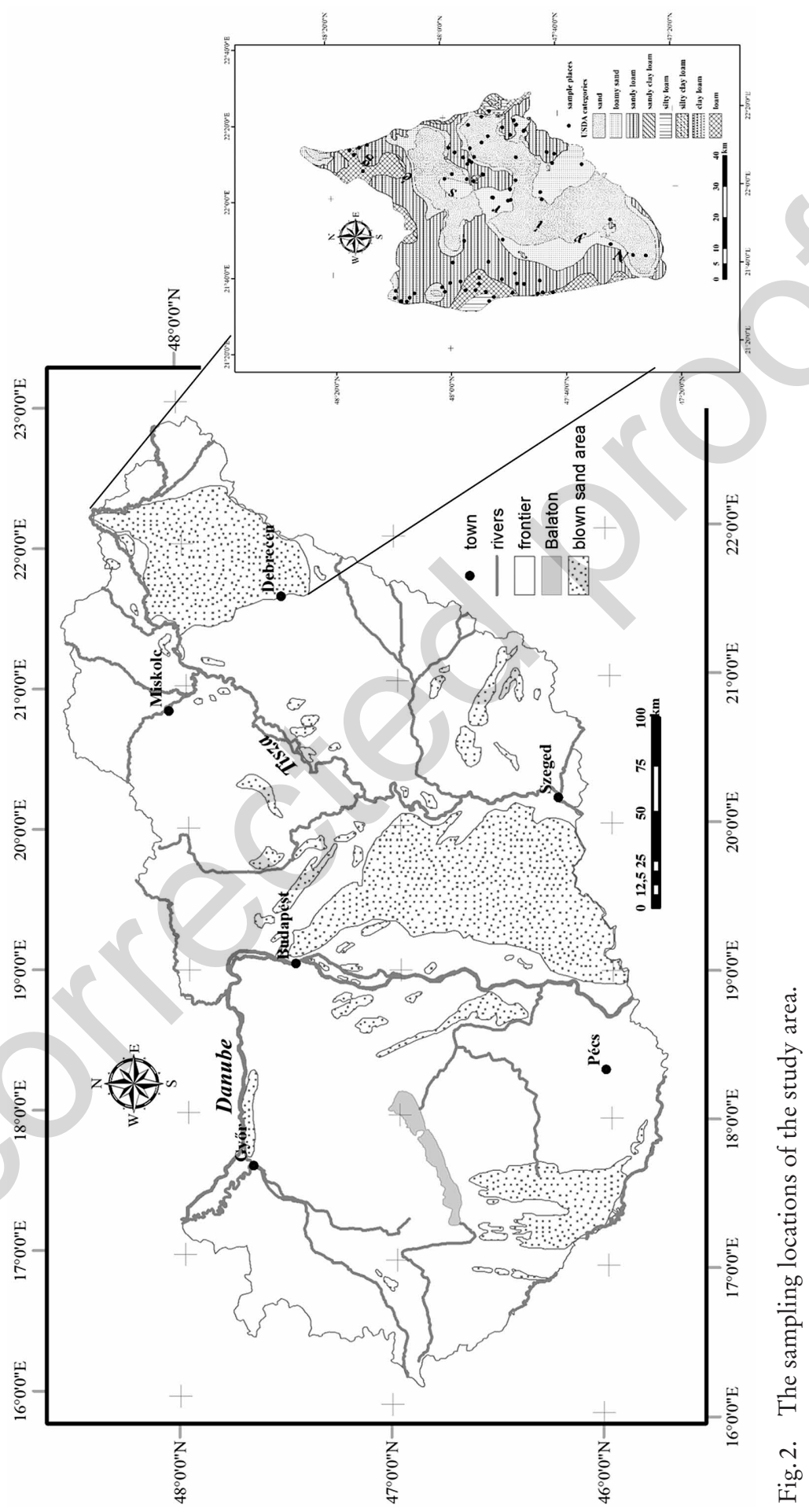


process was that each type should be represented by multiple samples, so that any possible differences between samples belonging to the same texture category would become comparable.

\subsection{Soil analyses}

Laboratory experiments were carried out in the laboratories of the Institute of Geosciences (University of Debrecen). Parts of the samples collected for wind erosion investigation from different locations were separated for sedimentology studies; these sample parts were then analyzed in respect to mechanical composition, $\mathrm{CaCO}_{3}$ and organic matter content, and $\mathrm{pH}$ value. Mechanical composition was determined by sieving and sedimentation/siltation (with Köhn-pipette; Köhn 1929). We used a Scheibler calcimeter to measure $\mathrm{CaCO}_{3}$ contents (TATZBER et al. 2007). Organic matter contents were determined by the Tyurin-method (SEO et al. 2004). Several pH (water and potassium-chloride based) measurements were also performed (ZBORAY \& SZALAI 2012).

The soil samples used in our experiments were classified according to the texture classification system developed by the USDA (SoIl Survey STAFF 1951). Subdivisions into the soil texture classes were determined according to a Hungarian particle size nomenclature developed for sand by Miнáctz (1933). This combined approach made possible to analyse the sand fraction in a detailed way.

\subsection{Wind tunnel experiments}

The wind erosion experiments were carried out in the blowing-type wind tunnel of the University of Debrecen (fig. 3). The working section of wind tunnel was $12.3 \mathrm{~m}$ (total length, from the ventilator fan to the filtering block), $0.80 \mathrm{~m}$ (width) and $0.50 \mathrm{~m}$ (height). Wind speed can be controlled continuously from 0 to $16.5 \mathrm{~m} / \mathrm{s}$ at $10 \mathrm{~cm}$ height. Wind speed was measured with a Testo 512 type differential manometer at the centre of the wind tunnel. The samples collected for the wind tunnel experiments were pretreated by drying in an exsiccator at $105^{\circ} \mathrm{C}$, then the air-dried soil samples were homogenized by a sieve (with $2 \mathrm{~mm}$ diameter) and put in $30 \times 50 \mathrm{~cm}$ long, $5 \mathrm{~cm}$ deep metal trays, in such a way that the sample surfaces were at the same level as the upper tray rim. A slope raising in acute angle was placed in front of the sample-holding trays in the wind tunnel, in order to prevent the air flow to hit the perpendicular tray wall, and so the resulting turbulence could be avoided. The experiments in the wind tunnel were carried out for different wind velocities.

There were two experiments in the study. Firstly, to determine the threshold wind speed for each sample a strong reflector was used which produced $70 \mathrm{~cm}$ long, $1 \mathrm{~cm}$ wide intensive trail of light. The velocity of wind was continuously increased until the initial movement of particles was observed visually. The wind velocity measured at $10 \mathrm{~cm}$ above the surface was considered as critical threshold velocity. The quantity of the solid material transported away by the wind in each test was calculated from the weight difference between the samples before and after the experiment, determined with accuracy to the gramm. The duration of every wind tunnel measurements was 5 minutes. All samples were measured three times, and the resulting data were averaged.

The samples collected for the wind tunnel experiments had various levels of humidity, thus, they were pretreated by drying in an exsiccator at $105^{\circ} \mathrm{C}$. The dried 


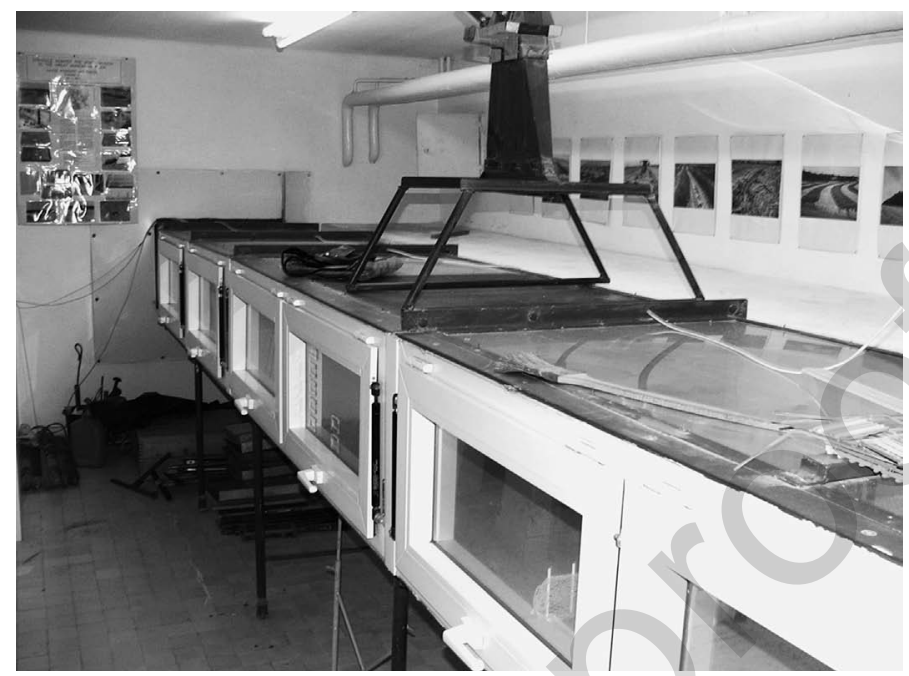

Fig. 3. The wind tunnel of the University of Debrecen.

soil samples were then homogenized by crumbling the united clods, then sieving through a wire-sieve (with $2 \mathrm{~mm}$ in diameter), in order to remove any pollutants (including stubble and weed residues, roots, etc.).

The thusly prepared dry soil samples were poured in $30 \times 50 \mathrm{~cm}$ long, $5 \mathrm{~cm}$ deep metal trays, in such a way that the sample surfaces were at the same level as the upper tray rim. A slope rising in acute angle was placed in front of the sample-holding trays in the wind tunnel, in order to prevent the air flow to directly hit the perpendicular tray wall, and so the resulting turbulence could be avoided. The experiments in the wind tunnel were carried out at different air flow velocities, and by measuring wind velocities at several heights from the sample surface. From the received data functions of the wind profiles above different soil types were calculated.

The quantity of the solid material carried away by the wind was calculated from the weight difference between the samples before and after the experiment, determined with accuracy to the gram. The duration of each measurement was 5 minutes. All samples were measured three times, and the resulting data were averaged. The accumulated data set was processed and analyzed in order to establish correlations between the measured parameters.

The quantitative data resulted from the wind tunnel experiments were used to determine the average thickness of the eroded soil samples, based on which, the studied soil types were categorized into different erosion risk classes. With the help of these risk categories and the soil distribution map of the study area, ArcGIS software was used to construct a potential wind erosion map based on the different soil texture classes. Taking the surface coverage into consideration by using the CORINE (2006) database, we removed all the areas which are either covered by permanent vegetation (forest, meadow, grass, etc.), or are otherwise effectively unaffected by wind erosion (built-up areas, fish ponds, etc.). Thus, four risk levels were determined for the studied area. 


\subsection{Spatial extension of the measured data}

Hungary's first detailed, digital soil map, displaying texture classes of top-soil according to USDA classification (SoIl Survey STAFF 1951) was compiled recently by PÁszTOR et al. (2011). Two national soil datasets were integrated in a specific, pedocentric way in order to combine their advantages.

The 1,200 observation locations of the Hungarian Soil Information and Monitoring System (SIMS; VÁrAllyay 2002) are characterized by detailed and up-to-date quantitative parameters, like particle size distribution data. The sampling pattern was not planned for mapping purpose; consequently, the sampling density does not allow the compilation of soil maps with finer scale than 1:1,500,000 (roughly 1,500 meter grid resolution; Hengl 2006). To achieve maps with better spatial resolution, the regionalization of SIMS data was supported by spatially more detailed, auxiliary soil information. Digital Kreybig Soil Information System (DKSIS), which is spatially the most detailed soil data-set covering the whole area of the country, is an adequate national spatial soil information system with appropriate data structure and great spatial resolution (PÁszTor et al. 2012) to be applied for this purpose.

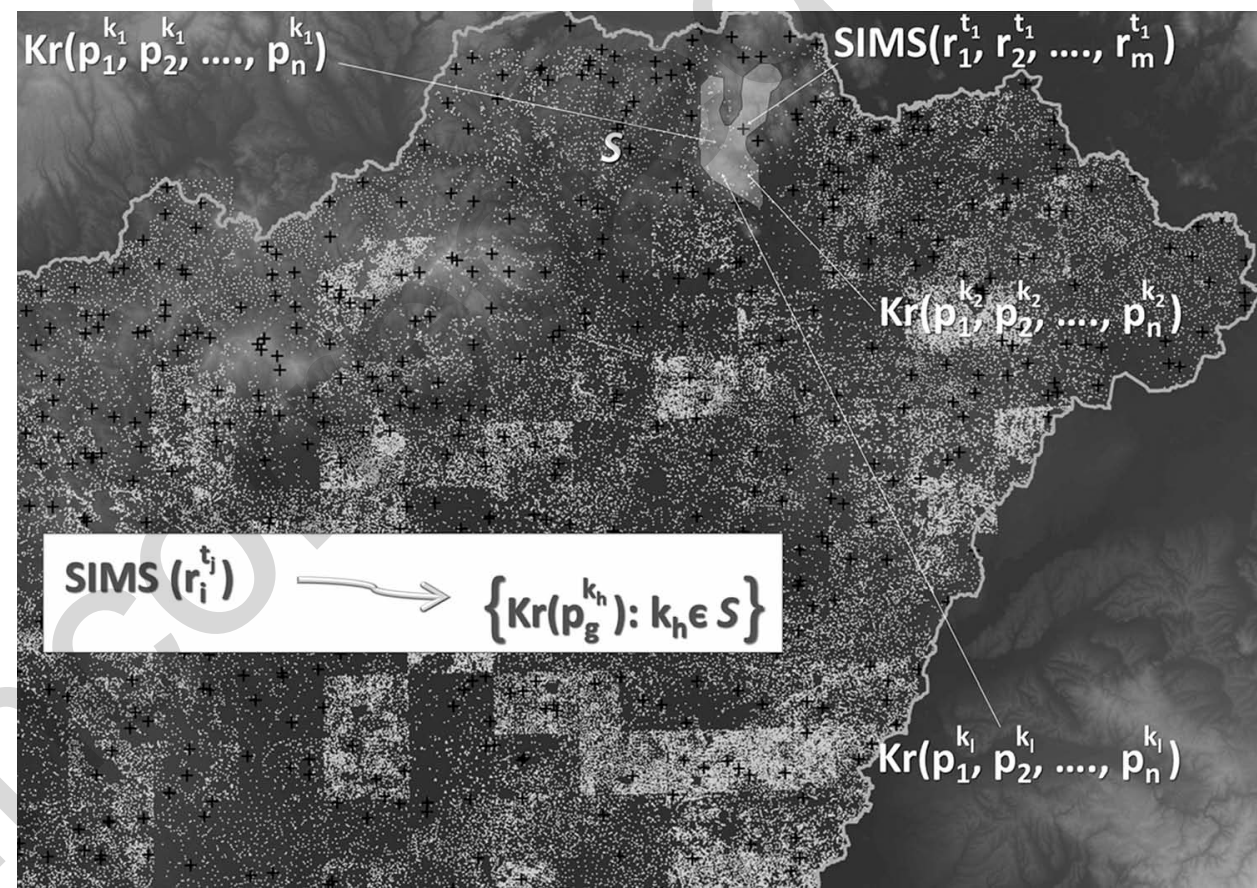

Fig. 4. The concept of integration of the two soil profile datasets. White dots represent the dense DKSIS soil profile locations featured by n soil parameters (p1, p2, .., pn), whereas black crosses are sparse SIMS observation sites featured by $\mathrm{m}$ soil parameters $(\mathrm{r} 1, \mathrm{r} 2, \ldots, \mathrm{rm})$. The white shape displays the identified area where a specific SIMS soil feature is predicted to be valid for DKSIS profiles according to the applied homology rule. 
The concept of soil homology originally introduced by MaLlavan et al. (2010) was relied on. The basic idea of our approach is the delimitation of a region where specific soil properties of a SIMS site are predicted to be valid. The profiles of DKSIS in the geographical neighborhood of a given SIMS location were tested according to a simple homology rule. The sites fulfilling the rule were identified as homosoil sites. The concept of this spatial inference method is sketched in figure 4 . The applied rule was established in the following manner.

The DKSIS soil profile database does not contain direct information on particle size distribution. However, physical soil parameters given by horizons (like hygroscopicity, 5 hours capillary rise values and plasticity index) can be used for a raw two-layer (topsoil + subsoil) FAO texture classification of soil profiles (BAKACsi et al. 2012). The SIMS profiles were similarly categorized. DKSIS profiles with identical two-layer classes within the same physiographical unit were identified as SIMS homosoil sites. As a result, roughly 14,000 locations could be used for the interpolation of quantitative soil physical parameters, as opposed to the original 1,200 SIMS sites.

Physical parameters of the soils, such as sand and clay content (in percentage) were mapped this way with a grid resolution of roughly $750 \mathrm{~m}$ ( 0.5 minutes). The interpolated values were used for the estimated localization of the soil texture of non-visited sites within the soil texture triangle. In figure 5 the cells lying within the

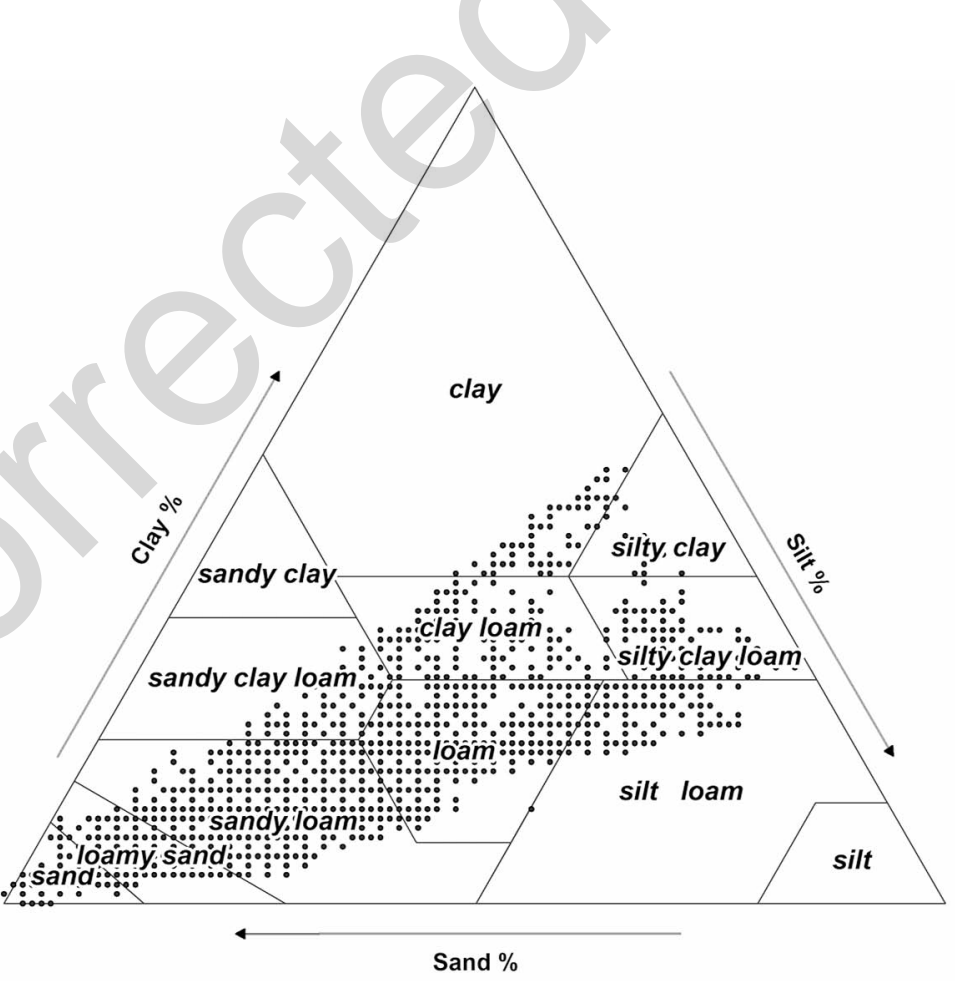

Fig. 5. The distribution of 0.5 minute cells within the soil texture triangle according to the interpolated sand and clay content percentage values. The subdivision of the triangle - according to USDA texture classification - is also displayed. 
Nyírség pilot area are plotted. According to the USDA classification subdivision, the great majority of the area is covered by soils belonging to one of the following four classes: sand, loamy sand, sandy loam and loam.

For the pilot area the raster map was converted into vector format. The effects of the raster-vector conversion were eliminated by proper generalization procedures. The spatial resolution of the resulted map is approximately $1: 50,000-1: 75,000$.

\section{$4 \quad$ Results and discussion}

\subsection{Results of the pedological characterization studies}

A significant part of the Nyírség area's surface is covered by soils with sand, loamy sand and sandy loam textures. Therefore, the majority of the samples were collected from such locations. Loam and silt loam can be found only in smaller patches. The physical and chemical properties of soil in different soil classes are presented in table 1.

\subsection{Threshold wind velocity values}

The threshold wind velocity for soils with sand texture varied between 5.7 and $8.1 \mathrm{~ms}^{-1}$. In general, experimental results point to an increase of threshold wind velocity in different samples in parallel to the decrease of their sand and increase of their silt and clay contents, together with a higher organic matter and $\mathrm{CaCO}_{3}$ ratio (fig. 6).

The threshold wind velocities for soils with loamy sand texture varied between 6.1 and $9.1 \mathrm{~ms}^{-1}$. These soil samples had lower sand contents, but still high enough to enable a relatively low threshold wind velocity, similarly to that of soils with sand texture. The change in velocity values is related primarily to particle size distribution. Higher velocities were detected at those samples where lower sand contents were coupled with higher silt and clay contents. In case of these soils it could be established again that higher $\mathrm{CaCO}_{3}$ +organic matter contents increased the threshold wind velocities (fig. 7).

Table 1. The averaged physical composition and $\mathrm{pH}$ values of the laboratory experiments performed on the collected samples.

\begin{tabular}{|c|c|c|c|c|c|c|c|}
\hline \multirow{3}{*}{$\begin{array}{l}\text { USDA texture classes } \\
(N) \text { number of soil sample }\end{array}$} & \multirow[t]{3}{*}{ sand } & \multirow[t]{3}{*}{ silt } & \multirow[t]{3}{*}{ clay } & \multirow{2}{*}{$\begin{array}{l}\text { organic } \\
\text { matter }\end{array}$} & \multirow[t]{2}{*}{$\mathrm{CaCO}_{3}$} & \multicolumn{2}{|c|}{$\mathrm{pH}$} \\
\hline & & & & & & $\mathrm{H}_{2} \mathrm{O}$ & $\mathrm{KCl}$ \\
\hline & & & & \multicolumn{4}{|c|}{ average (\%) } \\
\hline sand (19) & 90.84 & 6.54 & 2.63 & 1.00 & 2.14 & 5.57 & 5.00 \\
\hline loamy sand (21) & 80.80 & 14.82 & 4.38 & 1.41 & 2.83 & 5.94 & 5.32 \\
\hline sandy loam (25) & 66.15 & 26.87 & 6.98 & 2.62 & 5.26 & 6.49 & 6.04 \\
\hline loam (9) & 44.57 & 41.56 & 13.88 & 2.25 & 3.98 & 6.21 & 5.46 \\
\hline silty loam (6) & 33.83 & 56.82 & 9.35 & 3.19 & 5.66 & 7.19 & 6.93 \\
\hline
\end{tabular}



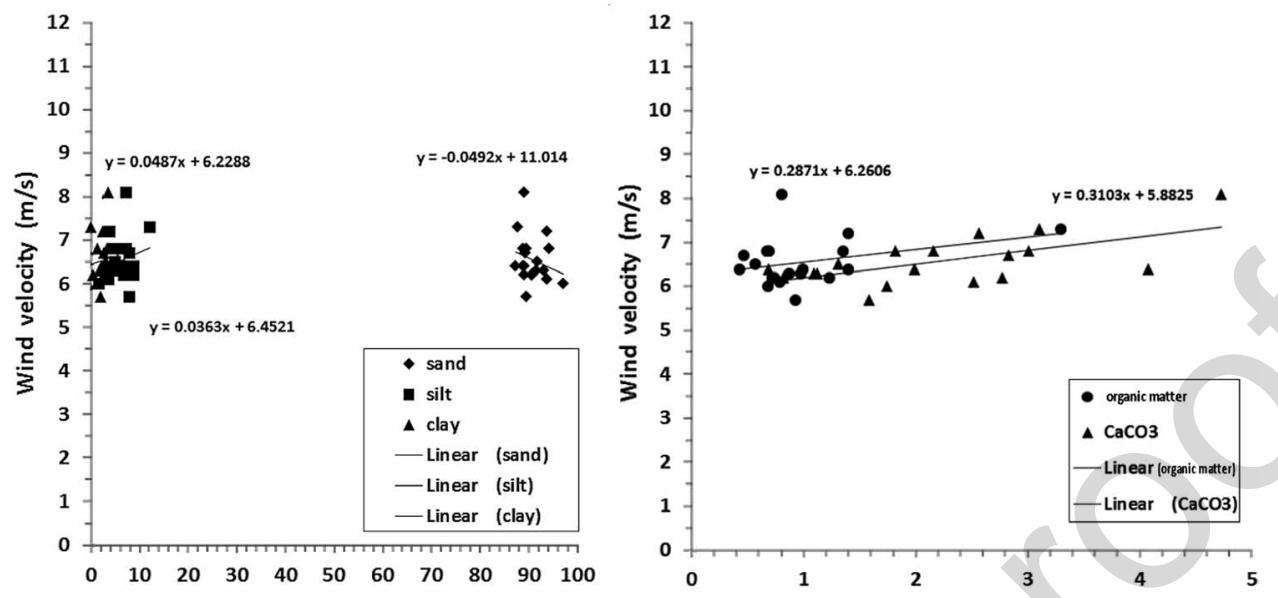

(\%)

Fig. 6. Correlations between particle distribution, organic matter and $\mathrm{CaCO}_{3}$ contents, and threshold wind velocities in case of soils with sand texture.
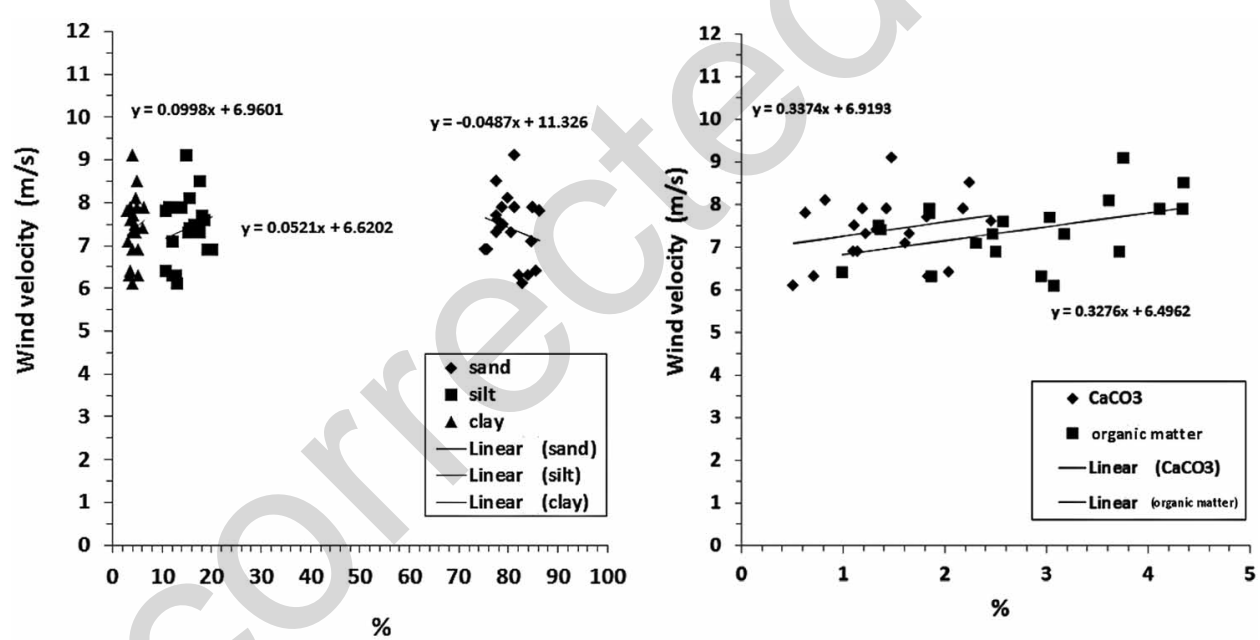

Fig.7. Correlations between particle distribution, organic matter and $\mathrm{CaCO}_{3}$ contents, and threshold wind velocities in case of soils with loamy sand texture.

Soils with sandy loam texture started to erode at higher threshold wind velocities than the previous two soil groups. The measured values varied between 7.4 and $9.8 \mathrm{~ms}^{-1}$. The most probable reason for this is that these samples had higher silt contents; therefore, higher kinetic wind energy was required to set the particles in motion. The higher the silt and clay content was, the higher velocity values were measured. The increase in organic matter and $\mathrm{CaCO}_{3}$ contents resulted in a higher threshold wind velocity for these samples as well (fig. 8). 

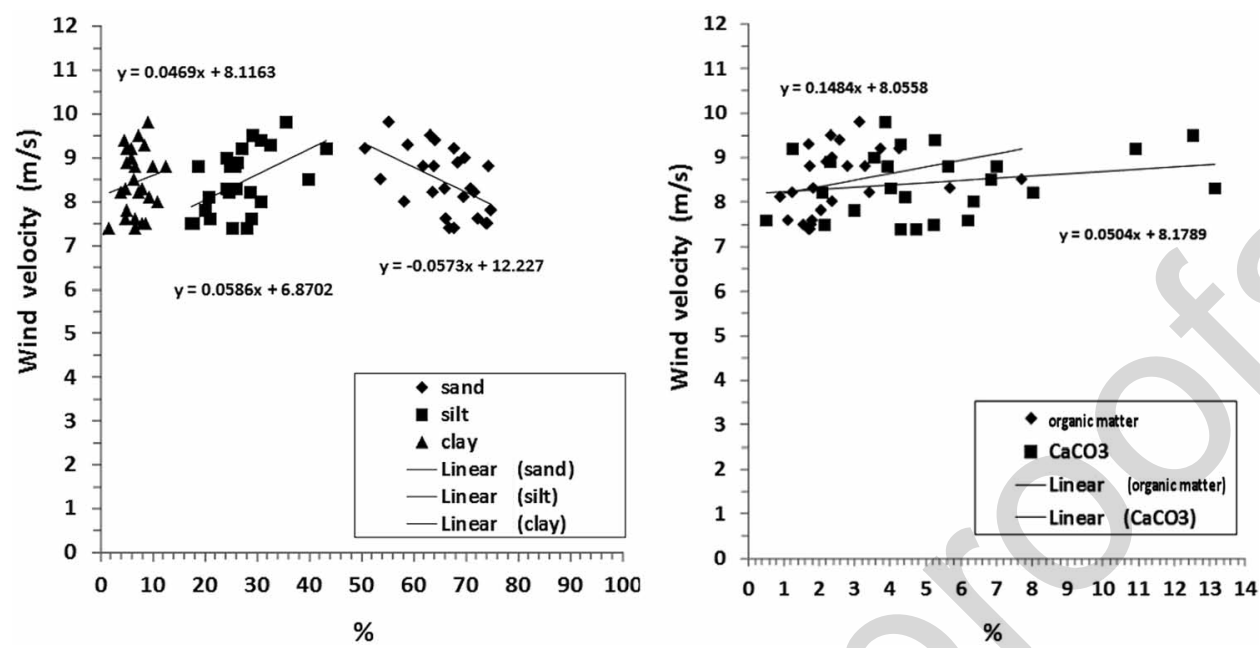

Fig. 8. Correlations between particle distribution, organic matter and $\mathrm{CaCO}_{3}$ contents, and threshold wind velocities in case of soils with sandy loam texture.
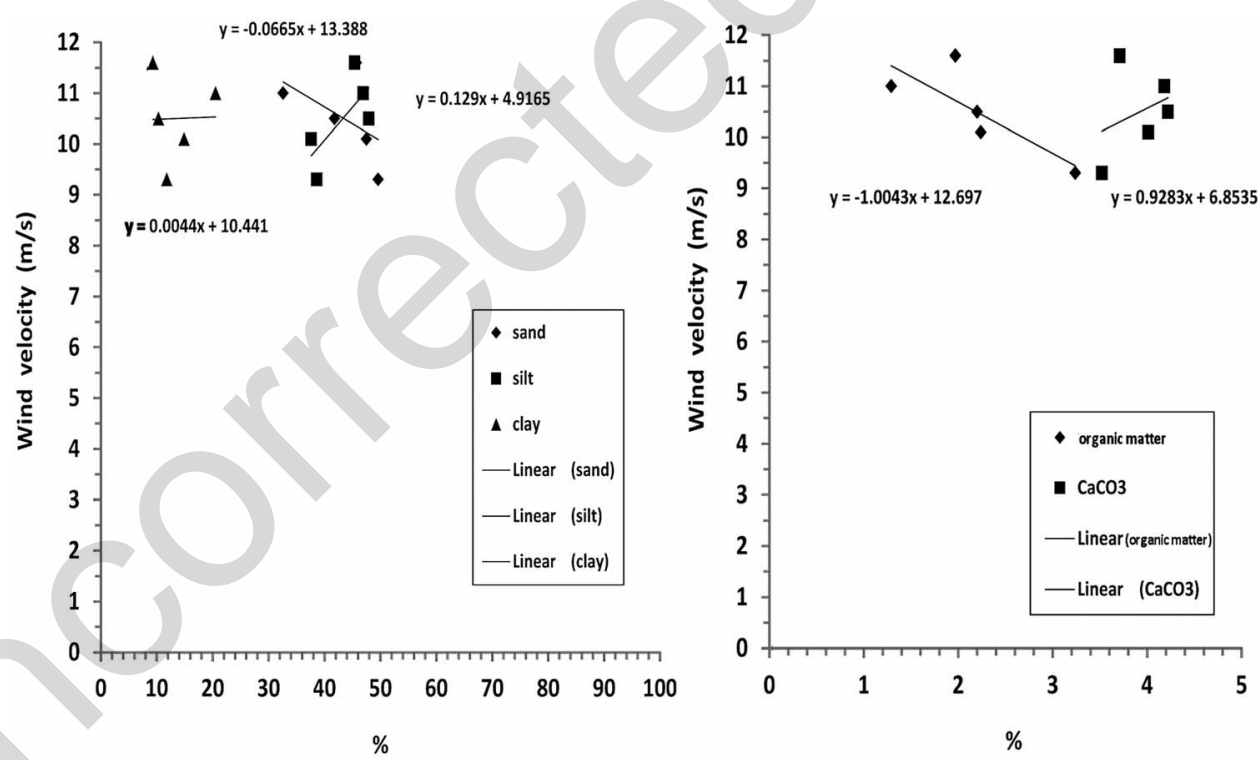

Fig. 9. Correlations between particle distribution, organic matter and $\mathrm{CaCO}_{3}$ contents, and threshold wind velocities in case of soils with loam texture. 
The threshold wind velocities for soils with loam texture varied between 9.3 and $11.6 \mathrm{~ms}^{-1}$. These soils could be abraded only by really strong winds. Such soil samples contained less than $50 \%$ sand fraction, whereas the dominant component was silt, and in some cases, also clay (fig. 9). The considerable increase of the threshold wind velocity values can be explained primarily by their higher silt and $\mathrm{CaCO}_{3}$ contents.

The threshold wind velocity for soils with silt loam texture varied between 10.0 and $11.6 \mathrm{~ms}^{-1}$, with an averaged value of $10.7 \mathrm{~ms}^{-1}$. These soil samples contained more than $50 \%$ silt (fig. 10). The highest threshold wind velocity values were measured for soil samples with the lowest sand ratio and the highest $\mathrm{CaCO}_{3}$ content.

Taking all experimental results into consideration, it can be established that the threshold wind velocity values were determined primarily by the mechanical structure and composition of the different soils, whereas within the same texture classes differences between organic matter and $\mathrm{CaCO}_{3}$ contents influenced these values.

\subsection{Results of the erodibility studies}

By evaluating the experimental data we established that the extent of erodibility depends primarily on the soil particle composition. Therefore, in the following section we present the erodibility values for each soil texture classes.

Soils belonging to the sand texture class were very sensitive to wind erosion. When evaluating the threshold wind velocities we already noted that the critical velocity for sand soils was an average $6.5 \mathrm{~ms}^{-1}$, but certain differences were found between the particular samples. The average soil mass loss at $13-15 \mathrm{~m} / \mathrm{s}$ wind velocity was found to be 5,000-6,000 g, which equals to the transportation of an approximately 25-27 mm thick layer (table 2). At threshols wind velocity the soil loss was
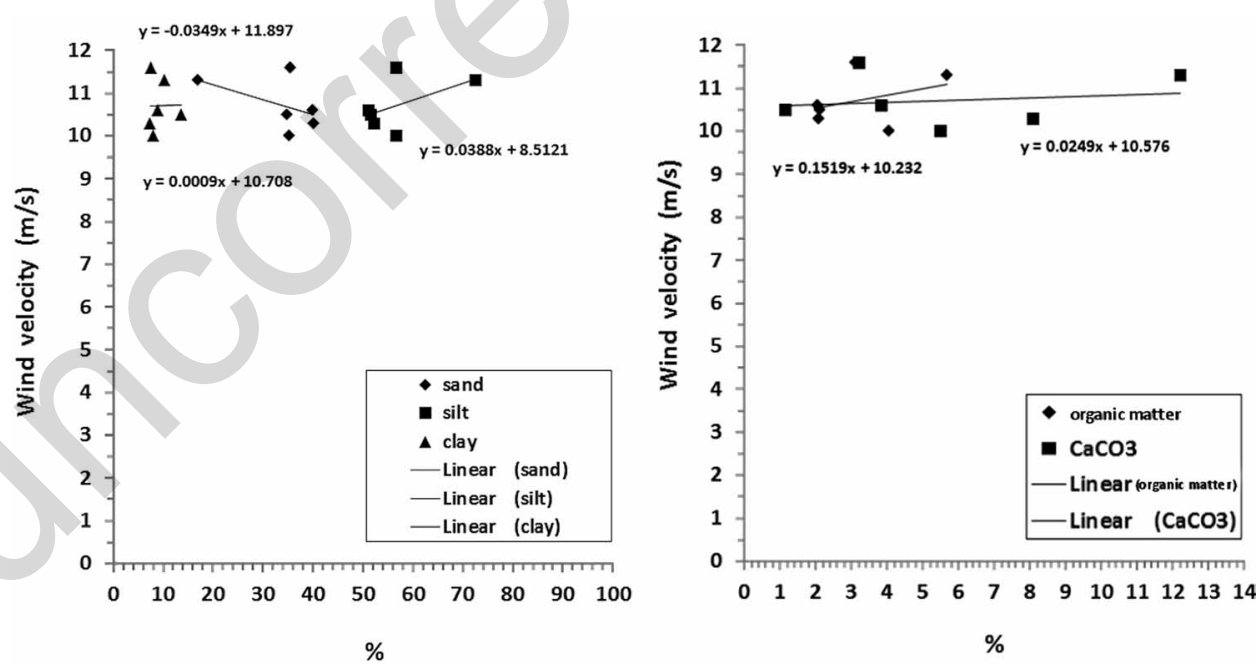

Fig. 10. Correlations between particle distribution, organic matter and $\mathrm{CaCO}_{3}$ contents, and threshold wind velocities in case of soils with silty loam texture. 
Table 2. Thickness of the transportd soil layer for each texture classes.

\begin{tabular}{llc}
\hline $\begin{array}{l}\text { USDA texture class } \\
(N) \text { number of soil samples }\end{array}$ & $\begin{array}{l}\text { wind velocity } \\
\mathrm{ms}^{-1}\end{array}$ & $\begin{array}{l}\text { transported soil } \\
(\mathrm{mm})\end{array}$ \\
\hline sand (19) & $13-15$ & $25-27$ \\
loamy sand (21) & $14-15$ & $22-25$ \\
sandy loam (25) & $14-15$ & $13-16$ \\
loam (9) & $14-15$ & $4-6$ \\
silty loam (6) & $14-15$ & $2-4$ \\
\hline
\end{tabular}

almost negligible; more substantial material displacement started only at about 10 $11 \mathrm{~ms}^{-1}$ wind velocity. Upon evaluating the results of the erodibility tests we determined the averaged values, then the functionality between the wind velocity values and the quantity of the transported soil materials (fig. 11). The trend lines fitted to the experimental results revealed an exponential correlation between these factors. With regard to the transported soil quantities at different wind velocities, differences were found between the different samples. These differences in the degree of erodibility were correlated to the change of organic matter and $\mathrm{CaCO}_{3}$ contents of the soils with different texture classes. The higher the organic matter and $\mathrm{CaCO}_{3}$ ratio a soil sample had, the lower erodibility value was measured.

The majority of the soil samples with loamy sand texture were humic sands with low organic matter content. At $14-15 \mathrm{~ms}^{-1}$ wind velocity an average 5,200-5,560 g mass loss was measured, which equals to the deflation of an about $22-25 \mathrm{~mm}$ thick soil layer. At threshold wind velocity the amount of eroded material was almost negligible; significant erosion started only at $13-14 \mathrm{~ms}^{-1}$ or above. The functionality between the wind velocity and the soil erosion was also found to be exponential (fig. 11), and the $\mathrm{R}^{2}$ value pointed to a close correlation. Differences in erodibility were also observed in case of soils with loamy sand texture - similarly to those with sand texture.

The third texture class is that of sandy loam, where the average threshold wind velocity was found to be $8.7 \mathrm{~ms}^{-1}$. This value also indicated that - because of the higher cohesive forces present between the granules - deflation starts slower at soils of this class. At $15.2 \mathrm{~ms}^{-1}$ wind velocity the average soil erodibility was $3,850 \mathrm{~g}$, which equals to the deflation of an about $16.5 \mathrm{~mm}$ thick soil layer. The steepness of the exponential function (fig. 11) indicates clearly that the amount of transported soil at $10.5 \mathrm{~ms}^{-1}$ on the average was less than half of the quantity measured in case of samples with sand texture at the same wind velocity. During the experiments we also noticed that winds with $11-12 \mathrm{~ms}^{-1}$ velocity or above tend to stir up a huge amount of dust into the air. In general, high-velocity winds transport the fine fraction to great distances from its original location. In turn, the removal of the fine granules from the top-soil would result in a gradual increase in erodibility of the soil.

In case of soils with loam texture the decrease of sand content and the increase of silt + clay ratio were reflected in their threshold wind velocity, which was averagely $10.5 \mathrm{~m} / \mathrm{s}$. Raising the velocity from the threshold value up to $13 \mathrm{~ms}^{-1}$ hardly any soil removal was detectable. At the highest velocity producable in the wind tunnel an 
increase in the quantity of dust carried by the air was observable again - the phenomenon being typical to soils with fine textures -, but the quantity of transported soil was significantly lower in comparison to the previous category. This is well indicated by the lower slope of the function as well (fig. 11). The average soil loss measured at $15.6 \mathrm{~ms}^{-1}$ wind velocity was found to be $2,080 \mathrm{~g}$, which equals to the removal of an about $6 \mathrm{~mm}$ thick soil layer.

In case of soils with silt loam texture, in order for the wind erosion to start, the wind velocity had to be increased to an average $10.7 \mathrm{~ms}^{-1}$. This value clearly indicates that these soils can be set in motion only by high-velocity winds with high kinetic energy. The first actual ablation values were only detectable at $11 \mathrm{~ms}^{-1}$. The average soil loss measured at a $15.7 \mathrm{~ms}^{-1}$ wind was $740 \mathrm{~g}$, which equals to the removal of an about $4 \mathrm{~mm}$ thick soil layer. Here the exponential function is even less steep than that of the soils with loam texture (fig. 11).

\subsection{A potential wind erosion risk map}

Using the averaged results of the wind tunnel experiments we calculated the quantity of the eroded soil at different wind velocities, and from that we determined the degree of transportation of soils belonging to different texture classes (table 3 ). Based on these results, in terms of susceptibility to wind erosion we classified the soils with sand and loamy sand textures as high risk; the sandy loam texture as moderate risk; and the silt loam and loam texture as low risk. The regional data of the map edited on the basis of soil texture classification (fig. 12a) are summarized in table 3 .

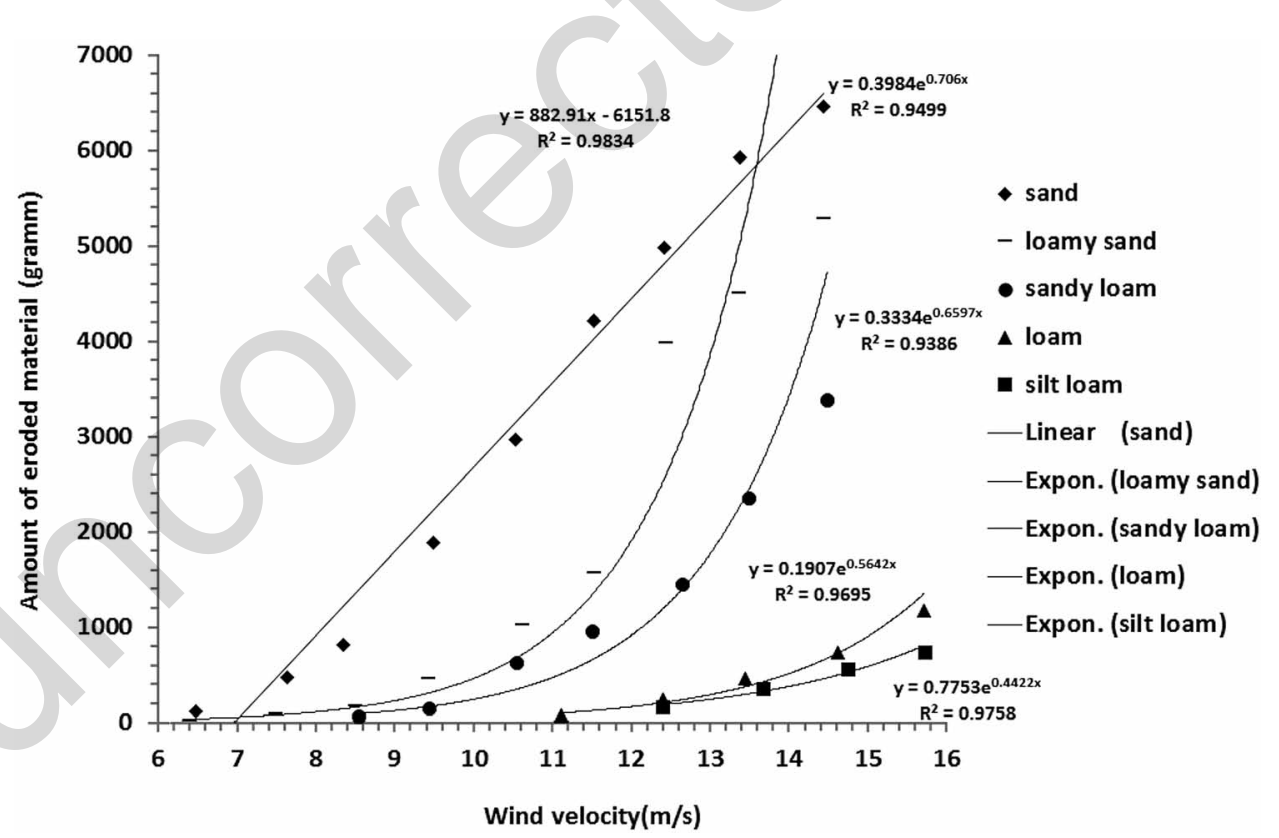

Fig. 11. Averaged erodibility curves for each texture classes of the soil samples collected from the Nyírség. 

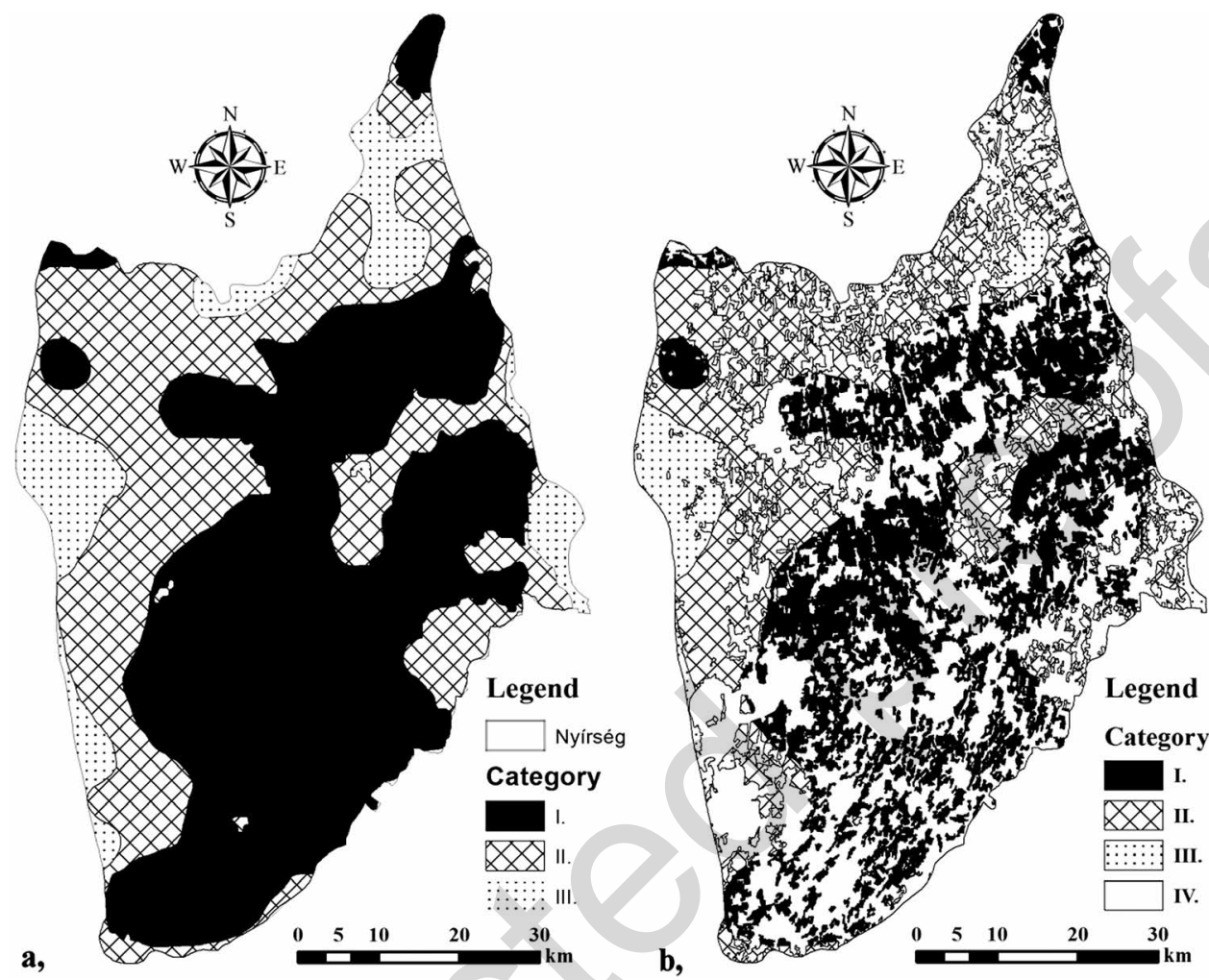

Fig. 12. The potential wind erosion risk maps of the Nyírség (a, based on soil texture classification; b, considering surface coverage as well) I. High risk, II. Moderate risk, III. Low risk, IV. No risk.

Table 3. The potential wind erosion risk categories summarized in area and percentage, based on different soil texture classes.

\begin{tabular}{lrr} 
& $\mathrm{km}^{2}$ & $\%$ \\
\hline High risk & $2,476.03$ & 54.0 \\
Moderate risk & $1,631.52$ & 35.6 \\
Low risk & 477.17 & 10.4 \\
& & \\
\hline Total & $4,584.72$ & 100.0
\end{tabular}

Table 4. The potential wind erosion risk categories summarized in area and percentage, based on different texture classes, also taking surface coverage into consideration.

\begin{tabular}{lrr}
\hline & \multicolumn{1}{c}{$\mathrm{km}^{2}$} & \multicolumn{1}{c}{$\%$} \\
\hline High risk & $1,198.53$ & 26.1 \\
Moderate risk & 997.13 & 21.7 \\
Low risk & 339.59 & 7.4 \\
No risk & $2,049.93$ & 44.7 \\
\hline Total & $4,585.18$ & 100.0 \\
\hline
\end{tabular}


The map constructed from the averaged experimental results and the CORINE (2006) database with the help of the soil texture map of the study area (fig. 12b) shows the potential erodibility of the Nyírség. The regional data of the map which also calculates with surface coverages (i. e. "no risk" areas) are summarized in table 4.

\section{Conclusions}

We carried out wind erosion experiments in a wind tunnel, on 80 samples collected from different locations of an almost $5,000 \mathrm{~km}^{2}$ area of alluvial plain that is covered mainly by soils with sandy and loamy textures. We determined the threshold wind velocities - as well as the degree of erodibility at various wind velocities - of the different soil types. Upon the evaluation of the resulting data, soils were classified in three risk categories in terms of wind erosion, then, also taking land cover into consideration, we constructed a potential wind erosion map of the study area. We established that in terms of wind erosion risk, the ratio of highly endangered areas - which are covered by soils with sand and loamy sand texture - exceeds $50 \%$. By now, as a result of the active protection against wind erosion and afforestation, the rate of highrisk areas has decreased to $26 \%$. A further very important task would be to develop and apply environmentally friendly soil conservation methods and strategies in the high and moderate risk areas. The GIS database - which includes pedological, wind erosion and surface coverage data as well - enables the area's evaluation in agricultural terms, and the development of an overall plan to protect against the damages from wind erosion.

\section{Acknowledgements}

The measurements and other part of the research were financed by the OTKA K83,560, OTKA K105,167 and TÁMOP-4.2.2/B-10/1-2010-0024 programs.

\section{References}

Andrews, B. D., Gares, P.A. \& Colby, J.D. (2002): Techniques for GIS modeling of coastal dunes. - Geomorphology 48: 289-308.

Ash, J.E. \& Wasson, R.J. (1983): Vegetation and sand mobility in the Australian desert dunefield. - Zeitschrift für Geomorphologie N. F., Suppl. 45: 7-25.

Bakacsi, Z., Kuti, L., Pásztor, L., Vatai, J., Szabó, J. \& Müller, T. (2010): Method for the compilation of a stratified and harmonized soil physical database using legacy and up-todate data sources. - Agrokémia és Talajtan 59: 39-46.

Borsy, Z. (1974): A futóhomok mozgásának törvényszerúségei és védekezés a szélerózió ellen/ Principles of sand movement and protection against wind erosion. - Manuscript, p. 322 (in Hungarian).

Fu, B. J., Zhao, W. W., Chen, L. D., Zhang, Q.J., Lü, Y.H., Gulinck, H. \& Poesen, J. (2004): Assessment of soil erosion at large watershed scale using RUSLE and GIS: a case study in the Loess Plateau of China. - Land Degradation and Development 16: 73-85.

Hengl, T. (2006): Finding the right pixel size. - Computers and Geosciences 32: 1283-1298.

KöHN, M. (1929): Korngrößenanalyse vermittels Pipettanalyse. - Tonindustrie-Zeitung 53: 729-731. 
LAL, R. (1994): Methods and guidelines for assessing sustainable use of soil and water resources in the tropics. - Prepared for Soil Management Support Services, U.S. Department of Agriculture Soil Conservation Service, and U.S. Agency for International Development, SMSS Technical Monograph 21. Ohio State University, Department of Agronomy.

LóKI, J. (2003): Mechanism of wind erosion and its effects in Hungary/A szélerózió mechanizmusa és magyarországi hatásai. - MTA doktori értekezés. Kézirat, p. 265 (in Hungarian).

Mallavan, B.P., Minasny, B. \& McBratney, A.B. (2010): Homosoil, a methodology for quantitative extrapolation of soil information across the globe. - Digital Soil Mapping, Progress in Soil Science 2, Springer, pp. 137-149.

Mináltz, I. \& UnGár, T. (1933): Distinction of eolian and fluvial sands. - Geological Bulletin 84: 17-28. (in Hungarian)

Oldeman, L. R., Hakkeling, R. T. A. \& Sombroek, W. G. (1991): World map of the status of human-induced soil degradation: An explanatory note. - Wageningen, The Netherlands and Nairobi, Kenya: International Centre and United Nations Environment Programme.

PÁsztor, L., BAKACsi, Z. \& SzABó, J. (2011): Spatio-temporal integration of soil data originating from different sources for the estimation of national carbon stock in Hungary. - Geophysical Research Abstracts, Vol.13, Vienna: EGU2011-10960, 1.

PÁsztor, L., Szabó, J., Bakacsi, Z. \& Laborczi, A. (2012): Elaboration and applications of spatial soil information systems and digital soil mapping at Research Institute for Soil Science and Agricultural Chemistry of the Hungarian Academy of Sciences. - Geocarto International 2012; 27: 1-15. doi:10.1080/10106049.2012.685895.

Prospero, J.M., Ginoux, P., Torres, O., Nicholson, S.E. \& Gill, T.E. (2002): Environmental characterization of global sources of atmospheric soil dust identified with the Nimbus 7 total ozone mapping spectrometer (TOMS) absorbing aerosol product. Reviews in Geophysics 40: 2-31.

SEO, M. C., So, K. H., Ko, B. G. \& Son, Y. K. (2004): Comparison of Tyurin method and dry combustion method for carbon analysis in soils of low inorganic carbon content. Korean Journal of Soil Science and Fertilizer 37: 315-321.

Shi, P., Yan, P., Yuan, Y. \& Nearing, M. A. (2004): Wind erosion research in China: past, present and future. - Progress in Physical Geography 28: 366-386.

Soll Survey StAfF (1951): Soil Survey Manual, USDA Handbook, 18. US Government Printing Office, Washington, DC.

Sweeting, M. M. \& LAncaster, N. (1982): Solutional and wind erosion forms on limestone in the central Namib Desert. - Zeitschrift für Geomorphologie N. F. 26: 197-207.

SzATMÁRI, J. (2006): Geoinformatikai módszerek és folyamatmodellek alkalmazása a széleróziós vizsgálatokban/Application of GIS methods and modells in wind erosion examinations. - Doktori értekezés, Szeged, Kézirat, p. 110 (in Hungarian).

Szabó, S. (2004): Evaluation of Some Soil Properties from the Aspect of Landscape Protection). Studia Geographica 13., Debrecen University Press, Debrecen, 152 p. (in Hungarian).

Tatzber, M., Stemmer, M., Spiegel, H., Katzbelger, C., Haberhauer, G. \& Gerzabek, M.H. (2007): An alternative method to measure carbonate in soils by FT-IR spectroscopy. - Environmental Chemistry Letters 5: 9-12.

VÁrallyay, G. (2002): Soil survey and soil monitoring in Hungary. - European Soil Bureau. Research Report 9: 139-149.

Visser, S. M., Sterk, G. \& Karssenberg, D. (2005): Wind erosion modelling in a Sahelian environment. - Environmental Modelling and Software 20: 69-84.

Webb, N.P., McGowan, H. A., Phinn, S. R. \& McTainsh, G.H. (2006): AUSLEM (AUStralian Land Erodibility Model): A tool for identifying wind erosion hazard in Australia. - Geomorphology 78: 179-200.

Webb, N. P., McGowan, H. A., Phinn, S. R., Leys, J. F. \& McTainsh, G. H. (2009): A model to predict land susceptibility to wind erosion in western Queensland, Australia. - Environmental Modelling and Software 24: 214-227. 
Zboray, N. \& Szalai, Z. (2012): Methods for determining the organic matter of soils (comparative analyses of analitycal procedures). - In: Physical geography researches in Hungary at the beginning of XXI. century, pp.163-168 (in Hungarian).

Manuscript received: October 2013; accepted: November 2013.

Addresses of the authors: Gábor Négyesi (corresp. author), University of Debrecen, Faculty of Sciences, Department of Physical Geography and Geoinformatics, H-4010 Debrecen, Egyetem tér1. E-Mail: negyesi.gabor@science.unideb.hu - József Lóki, University of Debrecen, Faculty of Sciences, Department of Physical Geography and Geoinformatics, H-4010 Debrecen, Egyetem tér1. E-Mail:loki.jozsef@science.unideb.hu - Botond Buró, University of Debrecen, Faculty of Sciences, Department of Physical Geography and Geoinformatics, H-4010 Debrecen, Egyetem tér1. E-Mail:bbotond86@gmail.com - József Szabó, Institute for Soil Science and Agricultural Chemistry, Centre for Agricultural Research, Hungarian Academy of Sciences (ISSAC CAR HAS), Herman O. u. 15, H-1022 Budapest, Hungary. E-Mail: szabo.jozsef@agrar.mta.hu - Zsófia Bakacsi, Institute for Soil Science and Agricultural Chemistry, Centre for Agricultural Research, Hungarian Academy of Sciences (ISSAC CAR HAS), Herman O.u. 15, H-1022 Budapest, Hungary. E-Mail: bakacsi.zsofia@agrar.mta.hu - László Pásztor, Institute for Soil Science and Agricultural Chemistry, Centre for Agricultural Research, Hungarian Academy of Sciences (ISSAC CAR HAS), Herman O. u. 15, H-1022 Budapest, Hungary. E-Mail: pasztor.laszlo@agrar.mta.hu 